\title{
Examining Saudi Students' Perceptions on the Use of the Blackboard Platform during the COVID-19 Pandemic
}

\author{
Elham Alzain \\ King Faisal University, Saudi Arabia \\ https://orcid.org/0000-0002-6330-3100
}

\begin{abstract}
The present study aims to examine students' perceptions on using the Blackboard learning system during the Covid-19 pandemic. The study investigates the effectiveness of the Blackboard on the students' learning during Coronavirus lockdown. It aims at finding out the difficulties and the challenges students face while using the Blackboard platform as a learning tool. It is expected that this study will contribute to the growing literature on the use of the Blackboard, mainly on its purposes to replace face-to-face learning/teaching process. Therefore, this study provides information about the learning experiences of Saudi students while the highly active use of the Blackboard and presents the challenges faced by the students during the online learning/teaching process. The study employs the quantitative research method as a questionnaire is used for collecting data. It is designed in Google format and emailed to the students. A sample of 270 respondents was selected from the Community College Abqaiq, King Faisal University. The method of analysis is descriptive statistical analysis, where the SPSS is employed for data analysis. The result reveals that students' perceptions are positive because students are aware of the benefit of the Blackboard platform during the COVID-19 pandemic. And when comparing choice preference between blended courses and online courses, students prefer blended courses. This is due to the challenges and difficulties that students face while using the Blackboard platform.
\end{abstract}

Keywords: blackboard; perspectives; online learning; challenges; COVID-19

\section{Introduction}

The spread of the COVID-19 has led many countries worldwide to take preventive measures. These measures have resulted in many changes at all levels, social interaction, and organization, including the education sector (Moawad, 2020; Murphy, 2020). Responding to the World Health Organization (WHO) and other organizations, many universities, colleges, schools, and 
institutions across the globe rapidly shifted from the face-to-face classroom to online learning systems. On 8 March 2020, the Saudi Ministry of Education called for virtual classes and distance education to ensure learning continuity during the suspension period (Desk, 2020; Tanveer et al., 2020). Therefore, many e-learning platforms have been used, and among these platforms is the Blackboard platform-one of the most widespread platforms used by universities in KSA. Before the COVID-19 pandemic, the online educational systems, i.e., e-learning platforms, have been used in many universities as complementary tools that help in the teaching and learning process.

However, with the spread of the COVID-19 pandemic around the globe, these online educational platforms are applied to replace face-to-face classrooms to protect communities, students, teachers, and professors from the pandemic and at the same time maintaining the continuation of education (Alturise, 2020; Coman et al., 2020; Sobaih et al., 2020). Likewise, the Blackboard system has helped teachers and students. It has been evolved from a complementary tool to a fundamental and an essential tool for completing the educational process during the COVID-19 pandemic that forces the universities to shut down their doors and go for online education. In Saudi Arabia, all public universities had taken up Blackboard as the primary learning management system (Al-Nofaie, 2020; Al Shammari, 2021; Khafaga, 2021; Mahyoob, 2020).

Concerning the Blackboard system in King Faisal University in general and the community college in particular, the Blackboard was mainly used for uploading lectures, study materials, assignments, and quizzes and hasn't been used for Blended learning. However, the Blackboard has been extensively used with the quarantine due to the coronavirus (COVID-19). That is to say, its role turns from a supplement to a primary instructional tool used not only for uploading and downloading lectures, course syllabi, study materials, assignments, homework, and quizzes but also for virtual classes, discussion, blogs, electronic exams, assignments, course messages, and other online synchronous and asynchronous activities. In a similar vein, students have been engaged in using the Blackboard for virtual learning classes, online chats, discussions, and other tasks instead of attending classrooms and face-to-face instructions. This sudden shift in the learning style has resulted in different perceptions in using the Blackboard as a learning tool in online learning. Therefore, this present study aims to identify students' perspectives using the Blackboard platform as a learning tool. The specific objectives are the following:

1. To explore the learning experiences of the Saudi students while using the Blackboard platform as a learning tool;

2. To find out the difficulties and the challenges students face while using Blackboard.

Keeping in view the above mentioned objectives, this study attempts to answer the following questions:

1. What are the students' perspectives of the Blackboard system?

2. What are the difficulties and challenges faced by college students in using the Blackboard system? 


\section{Literature Review}

Any academic research contributes to the already existent accumulation of human knowledge, and the current study is no exception. Thus, many people have studied such a topic-the Blackboard system: perspectives and challenges-from different angles. The present study aims to explore the students' learning experiences at the community college Abqaiq, King Faisal University, while using the Blackboard platform during Covid-19 quarantine.

Many previous studies have explained the importance of implementing the Blackboard with the teaching system. Alokluk (2018) points out that using Blackboard revolutionized the traditional system of the learning/teaching process and resulted in effective education. However, the Blackboard system is one of the early software that provided a virtual learning environment. It is widely used-especially in North America and Europe (Caputi \& Garrido, 2015) - and available in 12 different languages and is used by users in over 60 countries (Bradford et al., 2007 as cited in Al-Drees et al. 2015). As a component of the Learning Management System, many institutions have started using the Blackboard platform due to its easiness, ubiquity, and accessibility (Mohsen \& Shafeeq, 2014). In the last few years, the Blackboard platform has increasingly become popular among colleges and universities students and instructors across the globe (Al-Meajel \& Sharadgah, 2018). In the same sense, Blackboard has been defined as a software package that teachers can use to create high-quality online courses (Choy et al., 2005). Thus, the system is meant to support teaching and learning: promoting not only teacher-learner interaction but also interaction among students (Al-Naibi et al., 2015). The system is also provided with features and tools that enable the students to be engaged in learning outside the classroom anywhere and anytime (D'Silva \& Reeder, 2005).

Previous studies have revealed that the implementation of technological applications can be influenced by the users' perceptions and attitudes towards the systems and their use. Therefore, the users' preparedness and acceptance to use the system are essential for successful implementation (Almarabeh, 2014). Al-Drees et al. (2015) state that the "effective utilization of the Blackboard learning system mainly depends on students and faculty members' background, readiness and acceptance of such system" (p.17). Sheerah (2020) addressed the issue that using modern technology by practitioners is not merely a tool used to enhance the learning/teaching process but also to improve classroom activities and grant a better delivery of the curriculum. The study urged that face-to-face and online activities should be of equal importance. Examining the effectiveness of blended learning in self-directed learning within language skills, Banditvilai (2016) noted that blended learning has a positive advantage as the findings of the study show that online materials are beneficial to enhance language skills and autonomous learning. Pusuluri et al. (2017), in their research study at Al Jouf University, KSA, pointed out that the students neither agree nor disagree about the Blackboard offering a lively and exciting environment. However, the findings of their study imply that the Blackboard could be used as an effective medium to provide instructions motivations. Ja'ashan 2015 states that the students' perceptions and attitudes towards Blended Learning were positive, for it helps in enhancing their learning, motivating the interaction between teachers and students, and giving students enough time to do their tasks. However, the 
study also revealed negative impressions such as easy cheating, a waste of time, and social isolation.

Nyabawa 2016, in a case study, investigated the effects of using Blackboard Learn. The results of this research have shown a positive impact of Blackboard on students' performance. Similarly, Uziak et al. (2018) concluded that students were generally comfortable using Blackboard; their performance improved, and communication with instructors was enhanced significantly. Similarly, Ja' ashan (2020) pointed out that the students' attitude towards Blackboard is highly positive, and they are aware of the benefits of using E-learning. Hamad (2017), investigating the pros and cons of using Blackboard Collaborate for Blended Learning and its effect on students learning outcomes, stated that there are more advantages than disadvantages, and students are satisfied with using Blackboard Collaborate. Al-qahtani (2019) noted that the students' attitudes and perceptions towards using virtual classes are positively and negatively affected. The result of the study further revealed some advantages such as being easy to use and disadvantages such as having no sense of being in a real class.

However, Al-Maqtri (2014) conducted a case study at King Khalid University, KSA. The study concluded that teachers think that E-learning through Blackboard is effective, whereas students (male and female) do not consider Elearning effective. Similarly, Al Zumor et al. (2013) examined the effectiveness of using Blackboard in blended learning modules. The majority of participants (160 male EFL undergraduates) were generally dissatisfied with the blended learning courses and considered Blended learning less effective than face-to-face learning. Investigating the challenges and the difficulties for implementing the Blackboard system in the teaching/learning process, Al Meajel \& Sharadgah (2018) state that technological barriers and institutional barriers were the most highly identified barriers. Then the student barriers category came in the third level. Finally, the faculty barriers category ranked at the lower end.

Many studies and research papers have recently been conducted to examine online learning applications used during the COVID-19 pandemic, including the Blackboard Platform. One of these studies is the study conducted by Khafaga (2021) to explore how modern technologies contribute to the teaching/learning process in Saudi universities. This study concluded that Blackboard Collaborate prove to be useful for learning, both synchronously and asynchronously. Chen et al. (2020) sought to examine the perspectives of the Open University Australia students about the use of the Blackboard in online learning during the COVID19 pandemic. The results showed that students' perceptions about the Blackboard Collaborate were positive as a tool for real-time engagement, knowledge sharing, and feedback exchange.

Similarly, Elsamanoudy et al. (2020) reported that the Blackboard platform was a successful substitute for the traditional classes during the lockdown due to the COVID-19, as students were able to join sessions anytime, anywhere through any device. Almelhi (2021) reported that students had positive attitudes about using the Backboard platform due to its availability, system quality and convenience of use. Examining students' perceptions on Blackboard, Almekhlafy (2020) conducted a study to assess the online learning via Blackboard. The study concluded that the students' perceptions of the Blackboard were not positive. 


\section{Methodology}

This present study intends to explore the students' learning experiences at the community college Abqaiq, King Faisal University while using the Blackboard platform as a learning tool during COVID-19 quarantine. The study employed the quantitative research method as a questionnaire was used for collecting data. The method of analysis is a descriptive statistical analysis, where the SPSS version 26.0 is employed.

\subsection{Population and Participants}

The study's target population consists of 450 students (325 females and 125 males) who studied at Community College Abqaiq, King Faisal University. As it is essential to identify the people and the study sample and reasons for selection (Creswell \& Creswell, 2018), all the students joined the college after a preparatory year and share the same background i.e., already familiar with the Blackboard system and its application are chosen as the participants of this study. In this study, the data collection instrument was emailed to all the college students. The received valid responses 270 constitute the sample of this study. According to Thompson's (2012) equation the sample size of the population 450 should be 207 , which means $46 \%$ of the total population. However, the sample size of this study is $60 \%$. A large sample size helps to get more accurate results.

\subsection{Research Instrument and Data Collection}

The present study was limited to data collection through a questionnaire created with Google Forms and emailed to the students. Based on the theoretical framework and previous studies-mainly Uziak et al. (2018) and Ja'ashan (2020) - the data collection instrument was developed. The questionnaire comprises three sections: the first section was intended to obtain general information using the internet. It encompasses eight items. The second part investigates the use of the Blackboard as a learning tool. Finally, the third part was intended to obtain information on the challenges and the difficulties in using the Blackboard as a learning tool (See the Appendix). It was designed with a five-point Likert-type scale: (1) Strongly disagree; (2) Disagree; (3) Don't know; (4) Agree; (5) Strongly agree.

\subsection{Validity and Reliability of the Instrument}

The validity of the questionnaire was verified by sending the questionnaire to three experts. Some minor changes were suggested by the experts, and all agreed that the questionnaire was valid for measuring what it was meant forexamining Saudi students' perceptions on the use of the blackboard platform during the Covid-19 pandemic - and also suggested that for clarity, accuracy, and good understanding of the questionnaire, it is good to be translated into the mother tongue (Arabic) of the population of the study. Thus, a translated version was prepared, checked, and edited. The reliability of the data collection instrument has been tested using Cronbach's Alpha to verify the overall reliability of the questionnaire and the degree of internal consistency between its items. The Cronbach's alpha of all the questionnaire's items was of a high level of reliability (0.872). As the questionnaire of this study consists of three axes, the Stability coefficient of each axis is calculated. Table 1 shows the stability coefficient of the questionnaire's axes. The analysis shows a high degree of stability. The correlation of each axis and the internal consistency of its items are 
also calculated. The result shows that the correlation is significant at the 0.01 level (2-tailed).

Table 1. Cronbach's alpha measuring the stability of the questionnaire

\begin{tabular}{cccc}
\hline & Axis & Number of items & Alpha Cronbach \\
\hline 1 & The General use of Internet & 8 & 0.855 \\
\hline 2 & The Use of the Blackboard & 24 & 0.958 \\
\hline 3 & Challenges and Difficulties & 15 & 0.960 \\
\hline & The total & 47 & 0.872
\end{tabular}

\section{Results}

What are the students' perspectives of the Blackboard Platform?

The sudden shift to online learning and teaching due to the ongoing COVID-19 pandemic resulted in the exclusive use of the internet and technology. Students were not ready for this ongoing situation which requires them to use online platforms for learning. The Blackboard system was used by the King Faisal University and its affiliated colleges. To answer the first research question, it was necessary to obtain students' responses to the general use of the internet.

The students' responses of this section reveal, in general, a very high-level score, as they strongly agree/agree that they use the internet daily and use the internet for searching information, e-learning sources, and learning. Their responses also reveal that they have good skills in using the internet and technology; they strongly agree that the internet provides opportunities to develop creativity and strongly agree that the internet helps achieve assignments and tasks. Their responses positively range between the means of 4.54 and 3.85.

Table 2. Descriptive Statistics for the General Use of the Internet

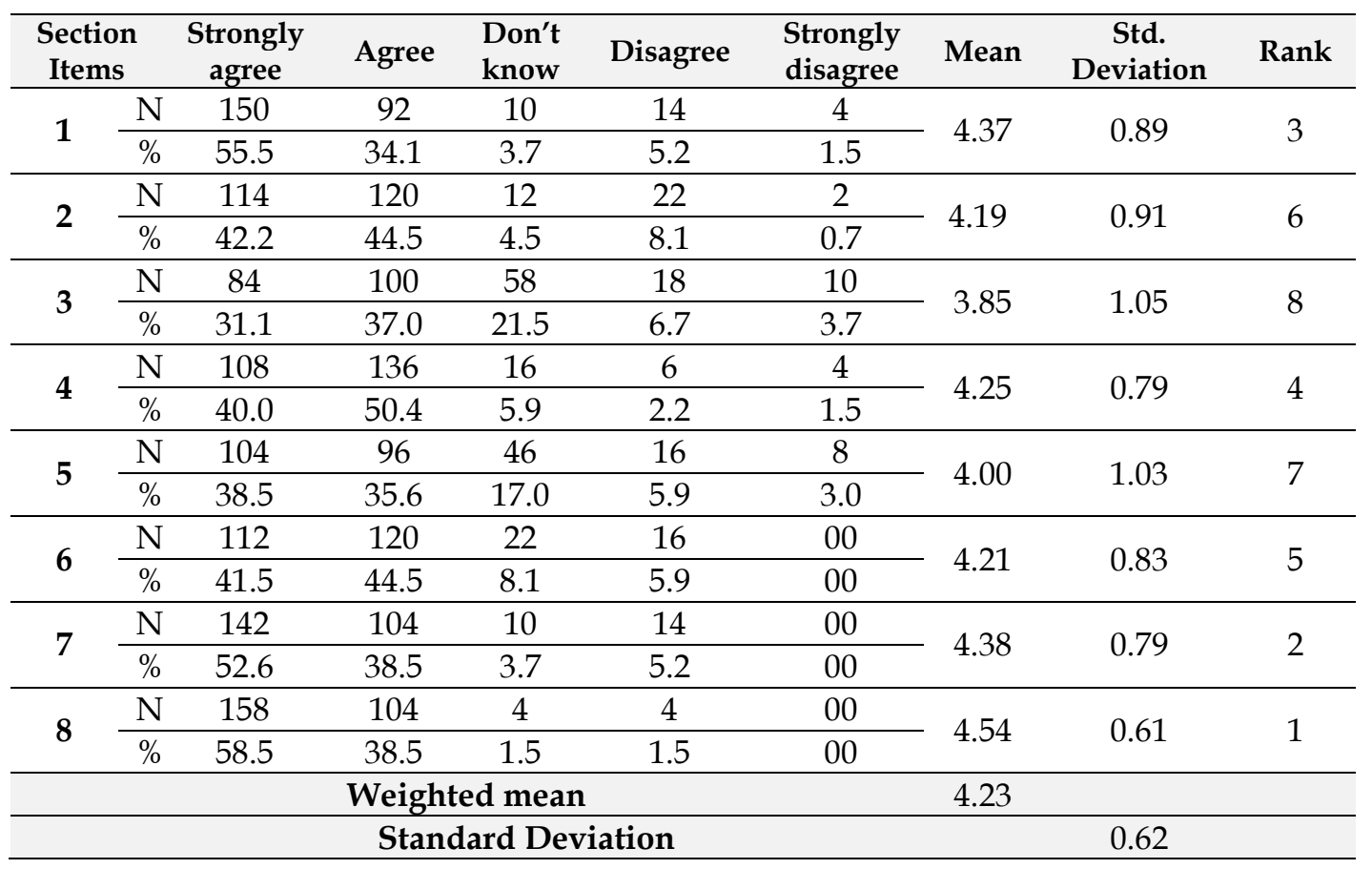


Table 2 shows the Descriptive Statistics for the General Use of the Internet. It illustrates that the highest score was given to item 8 (Internet helps achieve assignments and tasks) with a mean of 4.54 and a standard deviation of 0.61 . This is followed by item 7 (Internet provides opportunities to develop creativity) with a mean of 4.38 and a standard deviation of 0.79 . Then item 1 (I use the internet daily) comes next with the mean score of 4.37 and a standard deviation of 0.89. After that, item 4 (Internet helps you with your studies) and item 6 (Internet helps to provide e-learning sources) come next in order with the means score of $4.25(\mathrm{SD}=0.79)$ and $4.21(\mathrm{SD}=0.83)$, respectively. All these items account for strongly agree representing the percentage $58.5 \%, 52.6 \%, 55.6 \%, 40 \%$ and 41.5 respectively, and agree $38.5 \%, 38.5 \%, 34.1 \%, 50.4 \%$ and $44.4 \%$ respectively.

Item 2 (Use internet access for searching information) ranked 6th according to a mean score of 4.19 and a standard deviation of 0.91 , followed by Item 5 (Internet helps solve your learning problems) with a mean score of 4.00 and a standard deviation of 1.03. Item 3 (Have good technical skills in online searching) comes last with a mean score of 3.85 and a standard deviation of 1.05 with strongly agree by $42.2 \%, 38.5 \%$ and $31.1 \%$ respectively, and agree by $44.4 \%, 35.6 \%$ and 37.0 respectively.

The weighted average of this part is 4.23 , with a standard deviation of 00.62 . This indicates that the overall result of this part is "very high," as it lies in the range 4.21 - 5.00. Hence, the scope of the 5-point Likert scale is calculated as Very low 1 - 1.80, Low 1.81 - 2.60, Moderate 2.61 - 3.40, High 3.41 - 4.20, and Very High 4.21 - 5.00 .

Table 3 shows the students' perspectives on the use of the Blackboard as a learning tool. The students agree that they like to use the Blackboard; they agree that Blackboard is easy to use, and they want to learn more about Blackboard. The students also agree that the Blackboard is a good and positive educational tool, as it gives pleasure in learning and helps to enhance the quality of studies. Their responses positively range between the means 4.22 and 2.92 .

Table 3. Descriptive Statistics for the Use of Blackboard Platform as a learning tool

\begin{tabular}{|c|c|c|c|c|c|c|c|c|c|}
\hline \multicolumn{2}{|c|}{$\begin{array}{l}\text { Section } \\
\text { Items }\end{array}$} & \multirow{2}{*}{$\begin{array}{l}\begin{array}{c}\text { Strongly } \\
\text { agree }\end{array} \\
74 \\
\end{array}$} & \multirow{2}{*}{$\begin{array}{l}\text { Agree } \\
102\end{array}$} & \multirow{2}{*}{$\begin{array}{l}\begin{array}{l}\text { Don't } \\
\text { know }\end{array} \\
20\end{array}$} & \multirow{2}{*}{$\begin{array}{l}\text { Disagree } \\
46\end{array}$} & \multirow{2}{*}{$\begin{array}{l}\begin{array}{l}\text { Strongly } \\
\text { disagree }\end{array} \\
28 \\
\end{array}$} & \multirow{3}{*}{$\begin{array}{l}\text { Mean } \\
3.54\end{array}$} & \multirow{3}{*}{$\begin{array}{c}\begin{array}{c}\text { Std. } \\
\text { Deviation }\end{array} \\
1.33\end{array}$} & \multirow{3}{*}{$\begin{array}{l}\text { Rank } \\
20\end{array}$} \\
\hline 0 & $\mathrm{~N}$ & & & & & & & & \\
\hline 9 & $\%$ & 27.4 & 37.8 & 7.4 & 17.0 & 10.4 & & & \\
\hline \multirow{2}{*}{10} & $\mathrm{~N}$ & 102 & 98 & 20 & 32 & 18 & \multirow{2}{*}{3.86} & \multirow{2}{*}{1.23} & \multirow{2}{*}{8} \\
\hline & $\%$ & 37.8 & 36.3 & 7.4 & 11.9 & 6.7 & & & \\
\hline \multirow{2}{*}{11} & $\mathrm{~N}$ & 78 & 102 & 40 & 40 & 10 & \multirow{2}{*}{3.73} & \multirow{2}{*}{1.14} & \multirow{2}{*}{13} \\
\hline & $\%$ & 28.9 & 37.8 & 14.8 & 14.8 & 3.7 & & & \\
\hline \multirow{2}{*}{12} & $\mathrm{~N}$ & 34 & 68 & 42 & 104 & 22 & \multirow{2}{*}{2.95} & \multirow{2}{*}{1.21} & \multirow{2}{*}{24} \\
\hline & $\%$ & 12.6 & 25.2 & 15.6 & 38.5 & 8.1 & & & \\
\hline \multirow{2}{*}{13} & $\mathrm{~N}$ & 98 & 106 & 26 & 34 & 6 & \multirow{2}{*}{3.94} & \multirow{2}{*}{1.08} & \multirow{2}{*}{2} \\
\hline & $\%$ & 36.3 & 39.3 & 9.6 & 12.6 & 2.2 & & & \\
\hline \multirow{2}{*}{14} & $\mathrm{~N}$ & 94 & 104 & 26 & 42 & 4 & \multirow{2}{*}{3.89} & \multirow{2}{*}{1.09} & \multirow{2}{*}{6} \\
\hline & $\%$ & 34.8 & 38.5 & 9.6 & 15.6 & 1.5 & & & \\
\hline \multirow{2}{*}{15} & $\mathrm{~N}$ & 74 & 122 & 28 & 38 & 8 & \multirow{2}{*}{3.80} & \multirow{2}{*}{1.08} & \multirow[b]{2}{*}{10} \\
\hline & $\%$ & 27.4 & 45.2 & 10.4 & 14.1 & 3.0 & & & \\
\hline 16 & $\mathrm{~N}$ & 84 & 112 & 22 & 44 & 8 & 3.81 & 1.13 & 9 \\
\hline
\end{tabular}




\begin{tabular}{|c|c|c|c|c|c|c|c|c|c|}
\hline & $\%$ & 31.1 & 41.5 & 8.1 & 16.3 & 3.0 & & & \\
\hline \multirow{2}{*}{17} & $\mathrm{~N}$ & 72 & 88 & 22 & 70 & 18 & \multirow[b]{2}{*}{3.46} & \multirow{2}{*}{1.31} & \multirow{2}{*}{21} \\
\hline & $\%$ & 26.7 & 32.6 & 8.1 & 25.9 & 6.7 & & & \\
\hline \multirow{2}{*}{18} & $\mathrm{~N}$ & 54 & 110 & 30 & 58 & 18 & \multirow{2}{*}{3.45} & \multirow{2}{*}{1.22} & \multirow{2}{*}{22} \\
\hline & $\%$ & 20.0 & 40.7 & 11.1 & 21.5 & 6.7 & & & \\
\hline \multirow{2}{*}{19} & $\mathrm{~N}$ & 86 & 86 & 38 & 48 & 12 & \multirow{2}{*}{3.68} & \multirow{2}{*}{1.22} & \multirow{2}{*}{16} \\
\hline & $\%$ & 31.9 & 31.9 & 14.1 & 17.8 & 4.4 & & & \\
\hline \multirow{2}{*}{20} & $\mathrm{~N}$ & 78 & 100 & 40 & 30 & 22 & \multirow{2}{*}{3.67} & \multirow{2}{*}{1.23} & \multirow{2}{*}{17} \\
\hline & $\%$ & 28.9 & 37.0 & 14.8 & 11.1 & 8.1 & & & \\
\hline \multirow{2}{*}{21} & $\mathrm{~N}$ & 90 & 114 & 32 & 24 & 10 & \multirow{2}{*}{3.92} & \multirow{2}{*}{1.07} & \multirow{2}{*}{4} \\
\hline & $\%$ & 33.3 & 42.2 & 11.9 & 8.9 & 3.7 & & & \\
\hline \multirow{2}{*}{22} & $\mathrm{~N}$ & 86 & 114 & 26 & 40 & 4 & \multirow{2}{*}{3.88} & \multirow{2}{*}{1.06} & \multirow{2}{*}{7} \\
\hline & $\%$ & 31.9 & 42.2 & 9.6 & 14.8 & 1.5 & & & \\
\hline \multirow{2}{*}{23} & $\mathrm{~N}$ & 122 & 114 & 12 & 18 & 4 & \multirow{2}{*}{4.22} & \multirow{2}{*}{0.92} & 1 \\
\hline & $\%$ & 45.2 & 42.2 & 4.4 & 6.7 & 1.5 & & & 1 \\
\hline 24 & $\mathrm{~N}$ & 84 & 120 & 36 & 22 & 8 & & 102 & \\
\hline 24 & $\%$ & 31.1 & 44.4 & 13.3 & 8.1 & 3.0 & 3.92 & 1.02 & 3 \\
\hline 25 & $\mathrm{~N}$ & 72 & 102 & 52 & 36 & 8 & 371 & 109 & 14 \\
\hline 20 & $\%$ & 26.7 & 37.8 & 19.3 & 13.3 & 3.0 & $0 . / 1$ & 1.09 & 14 \\
\hline & $\mathrm{N}$ & 80 & 90 & 44 & 34 & 22 & 363 & & \\
\hline 20 & $\%$ & 29.6 & 33.3 & 16.3 & 12.6 & 8.1 & 3.63 & 1.20 & 18 \\
\hline 27 & $\mathrm{~N}$ & 82 & 106 & 32 & 36 & 14 & 376 & 117 & \\
\hline 27 & $\%$ & 30.4 & 39.3 & 11.9 & 13.3 & 5.2 & 0.10 & 1.17 & 12 \\
\hline 28 & $\mathrm{~N}$ & 74 & 136 & 30 & 20 & 10 & 390 & & \\
\hline 28 & $\%$ & 27.4 & 50.4 & 11.1 & 7.4 & 3.7 & 3.90 & 1.00 & 5 \\
\hline 29 & $\mathrm{~N}$ & 68 & 130 & 30 & 34 & 8 & 380 & 105 & 11 \\
\hline 29 & $\%$ & 25.2 & 48.1 & 11.1 & 12.6 & 3.0 & 0.00 & 1.00 & 11 \\
\hline & $\mathrm{N}$ & 68 & 116 & 40 & 28 & 18 & & 115 & \\
\hline 30 & $\%$ & 25.2 & 43.0 & 14.8 & 10.5 & 6.7 & 3.69 & 1.10 & 15 \\
\hline 31 & $\mathrm{~N}$ & 76 & 94 & 46 & 30 & 24 & 362 & 125 & 19 \\
\hline J & $\%$ & 28.1 & 34.8 & 17.0 & 11.1 & 8.9 & 0.02 & $1.2 \mathrm{~J}$ & 13 \\
\hline 32 & $\mathrm{~N}$ & 48 & 66 & 56 & 54 & 46 & 305 & 136 & 23 \\
\hline 32 & $\%$ & 17.8 & 24.4 & 20.7 & 20.0 & 17.0 & 0.00 & 1.00 & $2 \mathrm{~J}$ \\
\hline & ghte & mean & & & & & 3.71 & & \\
\hline & & & Star & $\operatorname{ard~De}$ & ation & & & 0.82 & \\
\hline
\end{tabular}

Table 3 shows the Descriptive Statistics for the Use of the Blackboard Platform. The results reveal that the Blackboard is very useful. The findings show that the highest average was given to item 23 (Blackboard helps to get course content) with a mean of 4.22 and a standard deviation of 0.92 , with strongly agree by $45.2 \%$, and agree by $42.2 \%$. This is followed by item 13 (Blackboard helps to do tasks \& assignments) with a mean of 3.94 and a standard deviation of 1.08 with strongly agree by 63.3 and agree by 39.3. Then item 21 (Blackboard gives the feeling that you are responsible for the learning process) and item 24 (It helps obtain the study material as Word, PDF, PowerPoint, audio, and video files) come next with a mean of 3.92 each and with a standard deviation of 1.07 and 1.02 respectively, with strongly agree by $33.3 \%$ and 31.1 respectively, and agree by $42.2 \%$ and $44.4 \%$ respectively. The other items of this section range from the means of 3.90 to 2.95. However, it is item 12 (I like to spend more time on Blackboard) and item 32 (Prefer to have courses delivered using Blackboard only) that come last in order of the items of this section with the mean of 2.92 
and 3.05 and a standard deviation of 1.21 and 1.36 respectively. Both items' value comes within "Moderate."

The weighted average of this part is 3.71 , with a standard deviation of 00.82 . This indicates that the overall result of this section (The Use of the Blackboard Platform as a learning tool) is "high," as it lies in the range $3.41-4.20$, according to the 5-point Likert scale.

What are the difficulties and challenges faced by college students in using the Blackboard system?

This section of the questionnaire tries to reveal the challenges and difficulties in using the Blackboard Platform as a learning tool. The students' responses of this section indicate, in general, a moderate level score, as their results, to some extent, show they face problems with the Blackboard Platform.

Table 4. Descriptive Statistics for the Challenges and Difficulties in the Use of the Blackboard Platform as a Learning Tool

\begin{tabular}{|c|c|c|c|c|c|c|c|c|c|}
\hline \multicolumn{2}{|c|}{$\begin{array}{l}\text { Section } \\
\text { Items }\end{array}$} & $\begin{array}{c}\text { Strongly } \\
\text { agree }\end{array}$ & Agree & $\begin{array}{l}\text { Don't } \\
\text { know }\end{array}$ & Disagree & $\begin{array}{l}\text { Strongly } \\
\text { disagree }\end{array}$ & Mean & $\begin{array}{c}\text { Std. } \\
\text { Deviation }\end{array}$ & Rank \\
\hline \multirow{2}{*}{33} & $\mathrm{~N}$ & 50 & 40 & 44 & 78 & 58 & \multirow{2}{*}{2.80} & \multirow{2}{*}{1.42} & \multirow{2}{*}{13} \\
\hline & $\%$ & 18.5 & 14.8 & 16.3 & 28.9 & 21.5 & & & \\
\hline \multirow{2}{*}{34} & $\mathrm{~N}$ & 68 & 40 & 16 & 90 & 56 & \multirow{2}{*}{2.90} & \multirow{2}{*}{1.52} & \multirow{2}{*}{11} \\
\hline & $\%$ & 25.2 & 14.8 & 5.9 & 33.3 & 20.7 & & & \\
\hline \multirow{2}{*}{35} & $\mathrm{~N}$ & 42 & 38 & 38 & 96 & 56 & \multirow{2}{*}{2.68} & \multirow{2}{*}{1.36} & \multirow{2}{*}{15} \\
\hline & $\%$ & 15.6 & $\begin{array}{l}14.1 \\
\end{array}$ & 14.1 & 35.6 & 20.7 & & & \\
\hline \multirow{2}{*}{36} & $\mathrm{~N}$ & 78 & 48 & 28 & 70 & 46 & \multirow{2}{*}{3.15} & \multirow{2}{*}{1.50} & \multirow{2}{*}{7} \\
\hline & $\%$ & 28.9 & $\begin{array}{ll}17.8 \\
\end{array}$ & 10.4 & 25.9 & 17.0 & & & \\
\hline \multirow{2}{*}{37} & $\mathrm{~N}$ & 70 & 18 & 34 & 90 & 58 & \multirow{2}{*}{2.82} & \multirow{2}{*}{1.51} & \multirow{2}{*}{12} \\
\hline & $\%$ & 25.9 & 6.7 & 12.6 & 33.3 & 21.5 & & & \\
\hline \multirow{2}{*}{38} & $\mathrm{~N}$ & 56 & 50 & 30 & 92 & 42 & \multirow{2}{*}{2.94} & \multirow{2}{*}{1.41} & \multirow{2}{*}{10} \\
\hline & $\%$ & 20.7 & 18.5 & 11.1 & 34.1 & 15.6 & & & \\
\hline \multirow{2}{*}{39} & $\mathrm{~N}$ & 78 & 40 & 30 & 66 & 56 & \multirow{2}{*}{3.06} & \multirow{2}{*}{1.54} & 0 \\
\hline & $\%$ & 28.9 & 14.8 & 11.1 & 24.4 & 20.7 & & & 9 \\
\hline 40 & $\mathrm{~N}$ & 96 & 76 & 14 & 54 & 30 & 357 & 142 & 3 \\
\hline 40 & $\%$ & 35.6 & 28.1 & 5.2 & 20.0 & 11.1 & 0.07 & 1.42 & 0 \\
\hline 41 & $\mathrm{~N}$ & 106 & 78 & 8 & 56 & 22 & 370 & 138 & 2 \\
\hline 41 & $\%$ & 39.3 & 28.9 & 3.0 & 20.7 & 8.1 & 0.70 & 1.00 & 2 \\
\hline 2 & $\mathrm{~N}$ & 134 & 78 & 10 & 38 & 10 & 406 & 120 & 1 \\
\hline 42 & $\%$ & 49.6 & 28.9 & 3.7 & 14.1 & 3.7 & 4.00 & 1.20 & 1 \\
\hline & $\mathrm{N}$ & 62 & 66 & 18 & 82 & 42 & & 145 & 8 \\
\hline 43 & $\%$ & 23.0 & 24.4 & 6.7 & 30.4 & 15.6 & 3.08 & 1.45 & 8 \\
\hline 44 & $\mathrm{~N}$ & 92 & 64 & 12 & 54 & 48 & 336 & 155 & 6 \\
\hline 44 & $\%$ & 34.1 & 23.7 & 4.4 & 20.0 & 17.8 & 3.30 & 1.35 & 6 \\
\hline 45 & $\mathrm{~N}$ & 88 & 78 & 10 & 48 & 46 & 342 & 151 & 5 \\
\hline 43 & $\%$ & 32.6 & 28.9 & 3.7 & 17.8 & 17.0 & 0.42 & 1.31 & 3 \\
\hline 16 & $\mathrm{~N}$ & 84 & 50 & 70 & 32 & 34 & 313 & 137 & 1 \\
\hline 40 & $\%$ & 31.1 & 18.5 & 25.9 & 11.9 & 12.6 & 0.40 & 1.07 & 4 \\
\hline 17 & $\mathrm{~N}$ & 44 & 50 & 38 & 70 & 68 & 74 & 11 & 14 \\
\hline $4 /$ & $\%$ & 16.3 & 18.5 & 14.1 & 25.9 & 25.2 & 2.74 & 1.43 & 14 \\
\hline & ghted & nean & & & & & 3.19 & & \\
\hline & & & Standa & d Devi & tion & & & 1.15 & \\
\hline
\end{tabular}


Table 4 shows the Descriptive Statistics for the Challenges and Difficulties using the Blackboard platform as a Learning Tool. The results are shown in Table 4 vary between the high level and the moderate level. For example, item 42 (Facing problem with the repeated interruptions) stands first with a mean of 4.06 and a standard deviation of 1.20. Then it is followed by item 41 (Facing problem with Blackboard log in) with a mean of 3.70 and a standard deviation of 1.38 . Then item 40 (Facing problem using the Blackboard platform) comes next with a mean score of 3.57 and a standard deviation of 1.42. After that, item 46 (Facing problem to communicate with the technical service center) comes next in order with a mean score of 3.43 and a standard deviation of 1.37. Item 45 (Facing problem in homework and assignments upload) comes next in order with a mean score of 3.42 and a standard deviation of 1.51 . These are the major problems for the students with "strongly agree" by $49.6 \%, 39.3 \%, 35.6 \%, 31.1 \%$ and $32.6 \%$ respectively and "agree" by $28.9 \%, 28.9 \%, 28.1 \%, 18.5 \%$ and $28.9 \%$ respectively.

However, the results also reveal a moderate average, as item 44 (Facing problem with homework and assignment download) with a mean of 3.36 and a standard deviation of 1.55, followed by item 36 (Using Blackboard gives me tension) with a mean of 3.5 and a standard deviation of 1.50, followed by item 43 (Facing difficulties to get the course content) with a mean of 3.08 and a standard deviation of 1.45, then followed by item 39 (I don't prefer using Blackboard for learning) with a mean of 3.06 and a standard deviation of 1.54, with "strongly agree" by $34.1 \%, 28.9 \%, 23.0 \%$, and $28.9 \%$ respectively, and with "agree" by $23.7 \%, 17.8 \%, 24.4 \%$, and $14.8 \%$ respectively. The average of the other items ranges between the means of 2.94 and 2.74 .

The weighted average of this section is 3.19 , with a standard deviation of 1.15 . This indicates that the overall result of this section (The Challenges and Difficulties in the Use of the Blackboard Platform as a Learning Tool) is "Moderate," as it lies in the range 2.61-3.40.

\section{Discussion}

Countries worldwide went into quarantine, and educational institutions have been compelled to shift from face-to-face classes to online courses (Alturise, 2020; Sobaih et al., 2020). This sudden shift has influenced the teaching process and teacher-student interactions and has generated changes in perceptions of online learning (Coman et al., 2020). This study aims to examine Saudi students' perceptions on the use of the Blackboard Platform during the COVID-19 pandemic. The result of this study reveals that students' perceptions are positive as the results show that students are aware of the benefit of the Blackboard platform during the COVID-19 pandemic. This result goes in line with Almelhi (2021), Chen et al. (2020), and Khafaga (2021), who reported that students have positive attitudes towards the Blackboard platform. However, Almekhlafy (2020) reported that the students' perceptions towards Blackboard were not positive.

Regarding the general use of the internet, the majority of the students reported that they use the internet on a daily basis for searching information, e-learning sources, and learning. Their responses also reveal that they have good skills in 
using the internet and technology. This goes in line with Al-Nofaie (2020), who reported that students are pretty good at using the computer, and comfortable surfing the internet.

Results further reveal that the Blackboard is very useful and user-friendly. The majority of the students reported that Blackboard helps to get course content, helps to do tasks \& assignments, and helps to obtain the study material as Word, PDF, PowerPoint, audio, and video files. This result is consistent with Alokluk (2018) and Al-Nofaie (2020), who reported that most of the students are comfortable with things like getting materials, doing searches, and downloading files. However, some students reported problems downloading the course content, and uploading homework and assignments. Furthermore, the majority of the students perceived that Blackboard gives the feeling that they are responsible for the learning process. This seems to chime with Hamad's (2017) and Khafaga's (2021) contention that Blackboard fosters independent learning. A further result is the students' perception that the Blackboard is a good and positive educational tool, as it gives pleasure in learning and helps to enhance the quality of learning. This reconciles with Nyabawa (2016) and Sheerah (2020), who concluded that the student academic performance is enhanced by frequent engagement on Blackboard, and with and Chen's et al. (2020) argument that Blackboard Collaborate enhances students' online learning. Moreover, the results show that using the Blackboard platform gives students the feeling of being engaged in the classroom. This result is similar to findings reported in prior studies: Chen et al. (2020), who reported that students were actively engaged in online sessions using the text chat, and Elsamanoudy et al. (2020), who concluded that students favored to be engaged in online sessions.

However, some students reported that using the Blackboard system caused tension. This result is consistent with Moawad (2020) in the sense that COVID-19 causes stress on online learning among students. Additionally, some students reported that they don't prefer using Blackboard. This result is commensurate with Al-Nofaie's (2020) findings which noted that many students become anxious in virtual sessions and thus they prefer physical interaction. One of the challenges that students encounter while accessing Blackboard is the repeated interruptions in the online classes. The results also show that they have a problem logging in to Blackboard. This result goes in line with Mahyoob's (2020) findings. A further issue that students reported is having difficulty communicating with the technical service center.

\section{Implications of the Study}

The findings of the study provide essential information about the necessity of having the Blackboard system not only as expanding learning possibilities but also as an inevitable and reliable tool for the educational process as well. Though the result shows the effectiveness of using the Blackboard, it also reveals a neutral level in using the Blackboard to increase the students' perception, and also shows no preference in having courses delivered using Blackboard only. Therefore, in the light of the review of the literature and the results of this study, the following recommendations can be made:

The universities and the colleges should have incentives that encourage students and faculty members to actively utilize Blackboard in the learning process; 
To make full and effective use of the Blackboard platform, a blended learning approach should be adopted into the learning process and should be used regularly rather than sporadically;

Students who show stress and tension should be reassured that all their activities and participations remain within the blackboard platform and are not accessible to everyone. This will help to reduce their anxiety and encourage them to use the Blackboard;

Interruptions happened during the online sessions and other technical problems may also cause tension and anxiety for students. These technical problems can be solved by reducing the load of the online courses and rescheduling the online sessions at different times of day.

Finally, this study will contribute to the development of online teaching/learning practices and will contribute to the existing literature on elearning.

\section{Conclusion}

The purpose of this study is to explore the students' perspectives on the use of the Blackboard platform at Community College Abqaiq. The results show that the students are aware of its benefits as a learning tool, and are customarily familiar with its use. The results also support the views that the internet provides opportunities to develop learners' creativity and helps in achieving assignments and tasks. As far as using the Blackboard platform as a learning tool, the students' responses reveal a high level of agreement (3.71 with a standard deviation 0.82 ), as it lies in the range $3.41-4.20$. The results suggest that the students actively use the Blackboard; to obtain the course content and study materials, do tasks and assignments; and communicate with teachers. Students' responses also reveal that the Blackboard helps in learning, enhancing the quality of the learning, and increasing the student's engagement with the learning. In addition, the results show that the students agree that the Blackboard gives the feeling of being responsible for the learning process and the feeling of being part of the classroom and teacher-student interaction. Though the students' responses show that they prefer to have blended courses delivered using Blackboard and traditional methods and agree that the virtual classrooms using the Blackboard platform are useful, they don't seem to prefer to have courses delivered using Blackboard only. However, the students' responses also reveal that they face problems and challenges while using the Blackboard, such as repeated interruptions while using the Blackboard platform, difficulties to login, difficulties in communicating with the technical service center, and problems to download and upload homework and assignments. In short, Blackboard platform is an attempt and a practice implemented to ensure the continuity of education, and because learners are urged to adapt/adopt new practices in the learning process, they remain skeptical to its practicality to a certain extent.

\section{Limitations}

The study has some limitations, which should be addressed in future research. First, this study was limited to a small sample size of the community college of Abqaiq in Saudi Arabia. Therefore, the findings of this research cannot be 
generalized to the entire country. Second, the research focused on the use of the Blackboard platform, meaning other research initiatives could be taken in the future that consider other online educational platforms. Third, since the study is conducted during the COVID-19 when the online education using the Blackboard is adopted to replace the face-to-face classroom, the study may not represent the entire online education practice in the country. Finally, the fact that the existing studies show various and contradictory results requires further research of students' perceptions of the Blackboard Platform.

\section{Acknowledgments}

The author acknowledges the Deanship of Scientific Research at King Faisal University for the financial support under Nasher Track (Grant no. 206104).

\section{References}

Al-Drees, A., Khalil, M. S., Meo, S. A., \& Abdulghani, H. M. (2015). Utilization of blackboard among undergraduate medical students: Where we are from the reality? Journal of Taibah University Medical Sciences, 10(1). https://doi.org/10.1016/j.jtumed.2014.07.002

Al-Maqtri, M. A. T. (2014). How Effective is E-learning in Teaching English? : A Case Study. . Journal of Education and Human Development. http://jehdnet.com/vol-3-no2-june-2014-abstract-39-jehd

Al-Nofaie, H. (2020). Saudi University Students' Perceptions towards Virtual Education During Covid-19 Pandemic: A Case Study of Language Learning via Blackboard. Arab World English Journal, 11(3). https://doi.org/10.24093/awej/vol11no3.1

Al-qahtani, M. S. (2019). The Relevance of Doing Virtual Classes: A Study of Postgraduate Female Students' Attitudes and Perceptions. Arab World English Journal, 1. https://doi.org/10.24093/awej/efl1.14

Al Meajel, T. M., \& Sharadgah, T. A. (2018). Barriers to Using the Blackboard System in Teaching and Learning: Faculty Perceptions. Technology, Knowledge and Learning, 23(2). https://doi.org/10.1007/s10758-017-9323-2

Al-Naibi, S. A., Madarsha, K. B., \& Ismail, N. A. (2015). Blackboard Use by Faculty Members in the Colleges of Applied Sciences in the Sultanate of Oman. International Journal for Innovation Education and Research, 3(4). https://doi.org/10.31686/ijier.vol3.iss4.345

Al Shammari, M. H. (2021). Devices and Platforms Used in Emergency Remote Learning and Teaching During Covid19: A Case of English Major Students in Saudi Arabia. Arab World English Journal, 1. https://doi.org/10.24093/awej/covid.6

Al Zumor, A. W., K. Al Refaai, I., A. Bader Eddin, E., \& H. Aziz Al-Rahman, F. (2013). EFL Students' Perceptions of a Blended Learning Environment: Advantages, Limitations and Suggestions for Improvement. English Language Teaching, 6(10). https://doi.org/10.5539/elt.v6n10p95

Almarabeh, T. (2014). Students' Perceptions of E-learning at the University of Jordan. International Journal of Emerging Technologies in Learning (IJET), 9(3). https://doi.org/10.3991/ijet.v9i3.3347

Almekhlafy, S. S. A. (2020). Online learning of English language courses via blackboard at Saudi universities in the era of COVID-19: perception and use. PSU Research Review, 5(1). https://doi.org/10.1108/PRR-08-2020-0026

Almelhi, A. M. (2021). The Role of the Blackboard LMS in EFL Course Delivery During the COVID-19 Pandemic: Investigating Attitudes and Perceptions of Faculty and Students. International Journal of English Linguistics, 11(2). 
https:// doi.org/10.5539/ijel.v11n2p46

Alokluk, J. A. (2018). The Effectiveness of Blackboard System, Uses and Limitations in Information Management. Intelligent Information Management, 10(06). https://doi.org/10.4236/iim.2018.106012

Alturise, F. (2020). Difficulties in Teaching Online with Blackboard Learn Effects of the COVID-19 Pandemic in the Western Branch Colleges of Qassim University. International Journal of Advanced Computer Science and Applications, 11(5), 74-81. https://doi.org/10.14569/IJACSA.2020.0110512

Banditvilai, C. (2016). Enhancing Students' Language Skills through Blended Learning. Electronic Journal of e-Learning, 14(3), 220-229. https:/ / eric.ed.gov/?id=EJ1107134

Bradford, P., Porciello, M., Balkon, N., \& Backus, D. (2007). The Blackboard Learning System: The Be All and End All in Educational Instruction? Journal of Educational Technology Systems, 35(3). https:/ / doi.org/10.2190/X137-X73L-5261-5656

Caputi, V., \& Garrido, A. (2015). Student-oriented planning of e-learning contents for Moodle. Journal of Network and Computer Applications, 53. https://doi.org/10.1016/j.jnca.2015.04.001

Chen, J. C., Dobinson, T., \& Kent, S. (2020). Lecturers' perceptions and experiences of Blackboard Collaborate as a distance learning and teaching tool via Open Universities Australia (OUA). Open Learning: The Journal of Open, Distance and eLearning, 35(3). https://doi.org/10.1080/02680513.2019.1688654

Choy, D., Xiao, J., \& Iliff, J. (2005). How can technology help improve the quality of Blackboard faculty training and encourage faculty to use Blackboard? . Annual Proceedings-Orlando, 1, 1, 130-134. https:/ / files.eric.ed.gov/fulltext/ED499958.pdf

Coman, C., Țîru, L. G., Meseșan-Schmitz, L., Stanciu, C., \& Bularca, M. C. (2020). Online Teaching and Learning in Higher Education during the Coronavirus Pandemic: Students' Perspective. Sustainability, 12(24). https://doi.org/10.3390/su122410367

Creswell, J. W., \& Creswell, D. J. (2018). Research Design Qualitative, Quantitative, and Mixed Methods Approaches (Fifth Edition). SAGE Publications, Inc. California.

D'Silva, R., \& Reeder, K. (2005). Factors that influence faculty members' uptake and continued use of course management systems. British Journal of Educational Technology, 36(6). https://doi.org/10.1111/j.1467-8535.2005.00578.x

Desk, W. (2020). Coronavirus outbreak: Saudi Arabia closes schools and universities. https:/ / www.geo.tv/latest/276467-coronavirus-outbreak-saudi-arabia-closesschools-and-universities

Elsamanoudy, A., Al Fayz, F., \& Hassanien, M. (2020). Adapting blackboard-collaborate ultra as an interactive online learning tool during the COVID-19 pandemic. Journal of Microscopy and Ultrastructure, 8(4). https://doi.org/10.4103/JMAU.JMAU_26_20

Hamad, M. M. (2017). Pros \& Cons of Using Blackboard Collaborate for Blended Learning on Students Learning Outcomes. Higher Education Studies, 7(2). https://doi.org/10.5539/hes.v7n2p7

Ja'ashan, M. M. N. (2015). Perceptions and Attitudes towards Blended Learning for English Courses: A Case Study of Students at University of Bisha. English Language Teaching, 8(9). https:// doi.org/10.5539/elt.v8n9p40

Ja'ashan, M. M. N. (2020). The Challenges and Prospects of Using E-learning among EFL Students in Bisha University. Arab World English Journal, 11(1). https://doi.org/10.24093/awej/vol11no1.11

Khafaga, A. F. (2021). The perception of blackboard collaborate-based instruction by EFL majors/teachers amid COVID-19: A case study of Saudi universities. Dil ve Dilbilimi Çalışmalan Dergisi, 17(2). https://doi.org/10.17263/jlls.904145

Mahyoob, M. (2020). Challenges of e-Learning during the COVID-19 Pandemic Experienced by EFL Learners. Arab World English Journal, 11(4). 
https://doi.org/10.24093/awej/vol11no4.23

Moawad, R. A. (2020). Online Learning during the COVID- 19 Pandemic and Academic Stress in University Students. Revista Romaneasca Pentru Educatie Multidimensionala, 12(1Sup2). https://doi.org/10.18662/rrem/12.1sup2/252

Mohsen, M. A., \& Shafeeq, C. P. (2014). EFL Teachers' Perceptions on Blackboard Applications. English Language Teaching, 7(11). https://doi.org/10.5539/elt.v7n11p108

Murphy, M. P. A. (2020). COVID-19 and emergency eLearning: Consequences of the securitization of higher education for post-pandemic pedagogy. Contemporary Security Policy, 41(3). https:// doi.org/10.1080/13523260.2020.1761749

Nyabawa, R. f. (2016). Technology in Learning: Blackboard Usage \& Its Impact on Academic Performance; A Case for Universities in Lesotho. International Journal of Humanities and Management Sciences (IJHMS), 4(5), 455-461. http://www.isaet.org/images/extraimages/P1216204.pdf

Pusuluri, S., Mahasneh, A., \& Alsayer, B. A. M. (2017). The Application of Blackboard in the English Courses at Al Jouf University: Perceptions of Students. Theory and Practice in Language Studies, 7(2). https:/ / doi.org/10.17507/tpls.0702.03

Sheerah, H. A. H. (2020). Using Blended Learning to Support the Teaching of English as a Foreign Language. Arab World English Journal, 6. https://doi.org/10.24093/awej/call6.13

Sobaih, A. E. E., Hasanein, A. M., \& Abu Elnasr, A. E. (2020). Responses to COVID-19 in Higher Education: Social Media Usage for Sustaining Formal Academic Communication in Developing Countries. Sustainability, 12(16). https://doi.org/10.3390/su12166520

Tanveer, M., Bhaumik, A., Hassan, S., \& Ul Haq, I. (2020). Covid-19 pandemic, outbreak educational sector and students online learning in Saudi Arabia. Journal of $\begin{array}{lll}\text { Entrepreneurship } \quad \text { Education, } & \text { 23(3), }\end{array}$ https://www.researchgate.net/publication/341519892

Thompson, S. K. (2012). Sampling (Third Edition). John Wiley \& Sons, Inc., Hoboken, New Jersey.

Uziak J, Oladiran T, Lorencowicz E, \& Becker K. (2018). Students' and Instructor's Perspective on the use of Blackboard Platform for Delivering an Engineering Course. The Electronic Journal of E-Learning, 16(1), 1-15. https://www.researchgate.net/profile/Jacek-Uziak/research 


\section{Appendix}

\section{Questionnaire}

Dear students

This is a questionnaire for the purpose of a research study. This study aims to examine Students' Perceptions on the use of the Blackboard Platform during the COVID-19 pandemic. There are 47 statements. Read each statement and choose one of the five options ((1) Strongly disagree; (2) Disagree; (3) Don't Know; (4) Agree; (5) Strongly agree.) that you think it best describes your choice.

\begin{tabular}{|c|c|c|c|c|c|c|}
\hline & Items & $\begin{array}{c}\begin{array}{c}\text { Strongly } \\
\text { agree }\end{array} \\
\text { a }\end{array}$ & Agree & $\begin{array}{l}\text { Don't } \\
\text { know }\end{array}$ & Disagree & $\begin{array}{l}\text { Strongly } \\
\text { disagree }\end{array}$ \\
\hline \multicolumn{7}{|c|}{ General use of Internet } \\
\hline 1 & I use internet daily. & & & & & \\
\hline 2 & $\begin{array}{l}\text { I use internet access for searching } \\
\text { information. }\end{array}$ & & & & & \\
\hline 3 & $\begin{array}{l}\text { I have good technical skills in online } \\
\text { searching. }\end{array}$ & & & & & \\
\hline 4 & Internet helps me with my studies. & & & & & \\
\hline 5 & $\begin{array}{l}\text { Internet helps to solve my learning } \\
\text { problems. }\end{array}$ & & & & & \\
\hline 6 & $\begin{array}{l}\text { Internet helps providing me with e- } \\
\text { learning sources. }\end{array}$ & & & & & \\
\hline 7 & $\begin{array}{l}\text { Internet provides opportunities to } \\
\text { develop creativity. }\end{array}$ & & & & & \\
\hline 8 & $\begin{array}{l}\text { Internet helps in achieving } \\
\text { assignments and tasks. }\end{array}$ & & & & & \\
\hline \multicolumn{7}{|c|}{ The use of the Blackboard as a learning tool } \\
\hline 9 & $\begin{array}{l}\text { I like using the blackboard } \\
\text { application. }\end{array}$ & & & & & \\
\hline 10 & Blackboard is user-friendly. & & & & & \\
\hline 11 & I like to learn more about blackboard. & & & & & \\
\hline 12 & $\begin{array}{l}\text { I like to spend more time using } \\
\text { blackboard. }\end{array}$ & & & & & \\
\hline 13 & $\begin{array}{l}\text { Blackboard helps in doing tasks and } \\
\text { assignments. }\end{array}$ & & & & & \\
\hline 14 & Blackboard is a good educational tool. & & & & & \\
\hline 15 & Blackboard helps in positive learning. & & & & & \\
\hline 16 & $\begin{array}{l}\text { Blackboard helps to enhance the } \\
\text { quality of learning. }\end{array}$ & & & & & \\
\hline 17 & $\begin{array}{l}\text { Blackboard gives me pleasure in } \\
\text { learning. }\end{array}$ & & & & & \\
\hline 18 & $\begin{array}{l}\text { The use of the blackboard increased } \\
\text { my perception. }\end{array}$ & & & & & \\
\hline 19 & $\begin{array}{l}\text { The use of blackboard increases my } \\
\text { effectiveness and my activity with } \\
\text { subjects. }\end{array}$ & & & & & \\
\hline 20 & Blackboard gives flexibility in time. & & & & & \\
\hline 21 & $\begin{array}{l}\text { Blackboard gives the feeling that you } \\
\text { are responsible for the learning } \\
\text { process. }\end{array}$ & & & & & \\
\hline 22 & $\begin{array}{l}\text { Blackboard gives the feeling that you } \\
\text { are part of the classroom. }\end{array}$ & & & & & \\
\hline
\end{tabular}




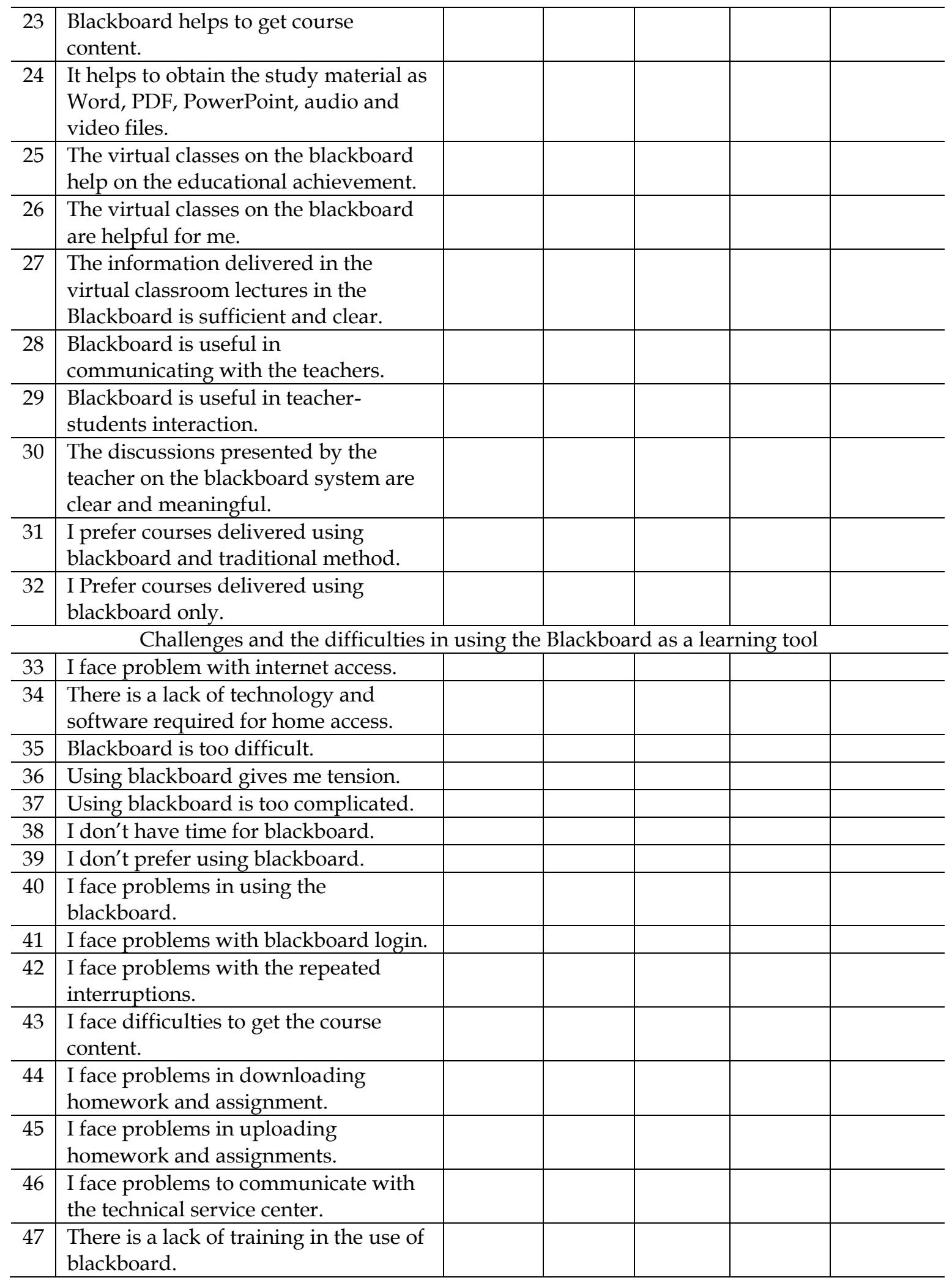

